\title{
Online Newspapers Providing Credible Information: A Survey of Indian Online News
}

\section{Readers}

\section{Pradeep Tewari, The Tribune Publication, India}

\begin{abstract}
An online survey was conducted among 3,183 online news readers in India. The aim of the survey was to know the reliable source of information of online readers and their reading habits, gadgets for online news reading, favourite news content, age group and gender. The questionnaire sent through the e-recourses (e-mail, Facebook, Twitter, and blog). Most of the online news consumers 60.3 percent $(n=1920)$ believe that websites of news organisations is the most credible source of information available on the Internet. As many as 97 percent online readers are also using traditional media for the news, 60.3 percent $(n=1909)$ respondents says text is the most favourite content for the news, 33.4 percent $(n=1063)$ like the photo gallery and 35 percent $(n=642)$ people are reading online news many times in a day. Majority of online readers are below the age of 30. 62 percent $(n=1941)$ are using smartphones for the online news.
\end{abstract}

Keywords: online news consumer, online news, Smartphone, Internet news, online survey. Introduction 
Today, with the development of Internet, technology communication system is changing rapidly. Communication is now much easier and cheaper with the help of Internet and print media is changing rapidly after the growth of digital technology around the world. As per various scholars, use of Internet and computer-mediated communication is increasing (Fox, Rainie, Larsen, Horrigan, Lenhart, Spooner, \& Carter, 2001; Horrigan, 2001; Nie \& Erbring, 2000; Nie, Hillygus, \& Erbring, 2002).

The online news has become the inherent part of modern society as it posed a challenge to the print media. Readership habits are changing as readers turn to the Internet for free and instant news. Instant news is one of the smart options of online media for the readers to accept it globally. As in print media reader can receive the news only once in a day. With the help of Internet on mobile phones (Smartphone), online news can be read anytime and anywhere. In India Smartphone users are growing fast due to affordable smart mobile devices. As per the research by US-based research firm eMarketer (2014), India will overtake the US as the second largest market for Smartphone in the world by 2016.

The beginning of New Communication Technology (NCT) gave opportunities and challenges for conventional media (Garrison, 1996). People are using Internet for two purposes, first it is used as mediated interpersonal technologies, which are for social bonding, relationship maintenance, problem solving, and persuasion. Second the Internet used as mass communication, which is for informational and leisure purposes (Flanagin \& Metzger, 2001). The Internet has attracted the many people around the world and has entered into people's daily lives. Many people read online newspapers because they highlight the breaking news of politics, crime, and accidents from all over the world, within minutes of the occurrence. The Chicago Tribune was the first newspaper, which started online newspaper after publishing its content in 1992 (Deuze, 1999). After 1992, the growth of online media is significantly grown. The World Wide Web has considerably influenced the journalism. Most of the traditional media television, radio, and newspapers start converting their news content digitally and started their websites. All the major newspapers of India have started their e-papers and online newspapers. As per Internet Live Stats, Internet users around the world are rapidly growing and 40 percent of the world population has an internet connection. In 2004, 14.1 percent people were using internet around the world and the number of internet users has increased nearly 26 percent in between 2004 - 2014. The latest research by the Internet and 
Mobile Association of India (IAMAI) and IMRB International shows that the Internet usage in India has gone up by 32 percent from October 2013 to October 2014. As per the report, 278 million people are using the internet in India till October 2014 and IAMAI is expecting 302 million people to use it by December 2014 in India.

Online media distinguish themselves from newspapers, radio, and television. Online media allows readers to share the news easily and provide the links to related news articles and most of the news portal allows their readers to comment on the information. As per the research online readers use news web sites "to get information that is unavailable elsewhere, for convenience, and the ability to search for news on a particular topic" (Pew Research Center [PRC], 1998). The mass media also started the use of internet. All the traditional media have started their online version, such as newspapers, radio, and television. Most of the time online information spread easily without being monitored by any system for the credibility of information except the media.

This research was conducted to examine the online reader's gender, behavior, interest, credibility of source of online information. It will provide a better understanding of what people read in online media and what are the favorite source of information? Finally, it will help to improve future online journalism.

\section{Review of Literature}

People do variety of things with the help of Internet, many people use Internet for email, chatting to keep in touch with friends and others around the world. Some of them play games on the Internet; others use Internet to get information through search engines. A study by Burgess and Jones (2010) found that males read newspapers more often than females, while females prefer to read books for fun and magazines more than their counterparts.

As per the Pew Research Center (1999), 'People go to the Internet increasingly as a source of information. Nearly half of all Internet users go to the Internet at least once every week to get information". Previous studies also suggest that Internet is used for information seeking (Mings, 1997; Stempel, Hargrove, \& Bernt, 2000; Ferguson \& Perse; Papacharissi \& Rubin, 2000; Flanagin \& Metzger, 2001). As per the research by Susan M. Mings of Rensselaer Polytechnic Institute, New York (1997), "people are more likely to use online newspapers 
when they look for specific topics, such as business. The online audience perceives online newspapers as more useful for getting particular information than scanning a printed paper". The presence of new media is a challenge to conventional media, especially the printed newspaper (Domingo \& Heinonen, 2008). As per the research U.S. newspaper industry is suffering through what could be its worst financial crisis since the Great Depression due to new media (Barthelemy et al., 2011).

According to the Pew Research Center (1998), "Internet audiences find the websites of various news organizations no more or less accurate than the information found in those organizations' traditional news outlets." Previous research has found evidence that people often use online news to supplement, not replace, their core news consumption (e.g., Althaus $\&$ Tewksbury, 2000). Readers always want to study the credible sources, or publications to get the information (Kaufman, Stasson \& Hart, 1999). Nowadays, most of the people without age bar around the world getting information from the internet for various purposes. Unfortunately, all of the information is not credible which they get from the internet (Wathen and Burkell, 2002).

Credibility is defines as "judgments made by a perceiver concerning the believability of a communicator" (Keefe, 1990). Differences in credibility of various type of information were noticed on the Internet. Most of the respondent thinks reference, news, and entertainment information are more credible than commercial information, whereas reference information was perceived to be more credible than entertainment information (Flanagin, \& Metzger, 2000). A survey by the Pew Research center found that 37 percent of online news users (and 51 percent of 18-29 year olds) think that commenting on news stories is an important feature to have, and that 25 percent of users have contributed their comments to online news articles (2010).

This research attempts to investigate the online newspapers popularity, frequency of the Internet usage for online news and what kind of news readers prefer. The gap is a considerable issue for the betterment of the online media. Why do online news readers are growing? This is the main purpose of this research project. 


\section{Objective}

Keeping in view the above discussion, the broader objects of the study was to assess the habits of online news consumers. The specific objectives of the study were as follows:

1. To evaluate online news readers gender.

2. To identify the age groups of online readers.

3. To find out the gadgets used for getting online news by news consumer.

4. To find out the reliable source of information on Internet.

5. To find out the frequency of getting news content.

\section{Methodology}

The online survey method was adopted to know the online readers habit in India. It is a most popular method to study the Internet users. It is a systematic gathering of data from the audience by sending e-mails to Internet users or posting questionnaire on social media and web pages. Respondents complete the questionnaire over the World Wide Web. Recent developments in the field of communication technologies have given choice of survey methods. Now with the help of internet on can do survey through e-mail, Web-based tools and Social media. Online survey have faster responses and save the time (Llieva, Baron, \& Healey, 2002), researcher can get data from a distant locations (Bachmann \& Elfrink, 1996; Garton et al., 2003; Taylor, 2000; Yun \& Trumbo, 2000).

In recent years an increase of online surveys have noticed for online studies, presenting scholars with new challenges in terms of applying traditional survey research methods to the study of online behavior and Internet use (Andrews, Nonnecke, \& Preece, 2003; Bachmann \& Elfrink, 1996; Stanton, 1998; Witmer, Colman, \& Katzman, 1999; Yun \& Trumbo, 2000). Responses of online surveys can be easily checked on the smart phone. Data can be immediately checked by the researcher via email, or posted to an HTML document or database file. It helps researchers to conduct preliminary analyses on collected data while waiting for the desired number of responses to accumulate (Llieva et al., 2002).

Online surveys are increasing in the last 10 years, conducting web or online surveys in comparison with other methods is low cost (Bachmann \& Elfrink, 1996; Couper, 2000; Llieva et al., 2002; Yun \& Trumbo, 2000). Web surveys have a number of advantages over other survey methods. They are convenient for respondents to take on their own time and 
save the time of a researcher as it is automatically stored electronically and analysis becomes easier.

For this study questionnaire was created on the Google Forms, a link of questionnaire posted on social media and mailed on various online news readers and provided links to the questionnaire on my own web page for six month July 1 to December 31, 2014. The questionnaires posed only close-ended questions. Questionnaire was checked by the other expert's one senior journalist of The Tribune Publication and two teachers of Mass Communication for the validation and reliability of questionnaire. After that the survey questionnaire was sent to 50 respondents to measure the reliability of questionnaire through the test-retest reliability method. The score of test-retest reliability was $r \geq 0.78$. The respondent for this survey were those who have the habit of reading news online and are of age groups between 15 and above. The data was collected by a questionnaire using web survey and findings and conclusions have been drawn based on the survey results.

\section{Data Analysis}

As per the previous studies online news readers are growing rapidly. Questionnaires were distributed through the internet, using e-recourses (e-mail, Facebook, Twitter, and blog) whiteout knowing the gender of respondents.

\section{Table 1: Gender of online news consumers}

\begin{tabular}{lcc}
\hline Gender of news consumer & Respondent $(\mathrm{n}=3183)$ & Percent of respondent \\
\hline Male & 2064 & 64.80 \\
Female & 1119 & 35.20
\end{tabular}

The table number 1 shows gender wise distribution of respondents, male are reading online news more than women. Among the 3183 respondents, 64.80 percent $(n=2064)$ male and 35.2 percent (1119) were female. 


\section{Table 2 : Use of traditional media}

\begin{tabular}{llllll}
\hline & & & & Percent & of \\
Traditional media & $\begin{array}{l}\text { Respondent } \\
(\mathrm{n}=3183)\end{array}$ & $\begin{array}{l}\text { Percent } \\
\text { respondent }\end{array}$ & $\begin{array}{l}\text { Percent of men } \\
(\mathrm{n}=2064)\end{array}$ & $\begin{array}{l}\text { women } \\
(\mathrm{n}=1119)\end{array}$ \\
\hline Yes & 3087 & 97 & 97 & 100 \\
No & 123 & 3 & 3 & -
\end{tabular}

The table- 2 shows the displacement effect of online newspapers is very low. Only 3 percent of the respondents have stopped the use of traditional media. While 97 percent online readers are using traditional media for the news, interestingly all the women respondents are still using traditional media.

Table 3: Age of respondents

\begin{tabular}{lllll}
\hline $\begin{array}{l}\text { Age } \\
\text { group }\end{array}$ & $\begin{array}{l}\text { Respondent } \\
(\mathrm{n}=3183)\end{array}$ & $\begin{array}{l}\text { Percent of } \\
\text { respondent }\end{array}$ & $\begin{array}{l}\text { respondents } \\
(\mathrm{n}=2064)\end{array}$ & $\begin{array}{l}\text { Percent of female } \\
\text { respondents }(\mathrm{n}=1119)\end{array}$ \\
\hline $15-20$ & 694 & 21.80 & 19.6 & 25.8 \\
$20-30$ & 1329 & 41.80 & 40.3 & 44.7 \\
$30-40$ & 564 & 17.8 & 19.7 & 14 \\
$40-50$ & 354 & 11.7 & 11.4 & 10.5 \\
$50-$ & & & & 5 \\
above & 242 & 7.6 & 9 &
\end{tabular}

The table 3 shows the maximum 41.80 percent $(n=1329)$ respondents were from 20-30 age group and 40.3 percent were male and 44.7 percent were women. While 21.80 percent ( $n=694)$ were from 15-20 age group, in this group women respondents were 25.8 percent and man 19.6 percent. 17.8 percent $(n=564)$ respondents were from $30-40$ age category, in this category male respondents were 19.7 percent and women 14 percent, followed by 40-50 age category 11.7 percent $(n=354)$ and 50 -above age category 7.6 percent, in this category 5 percent respondent were women and 9 percent male. 
Table 4: Gadgets used to get online news

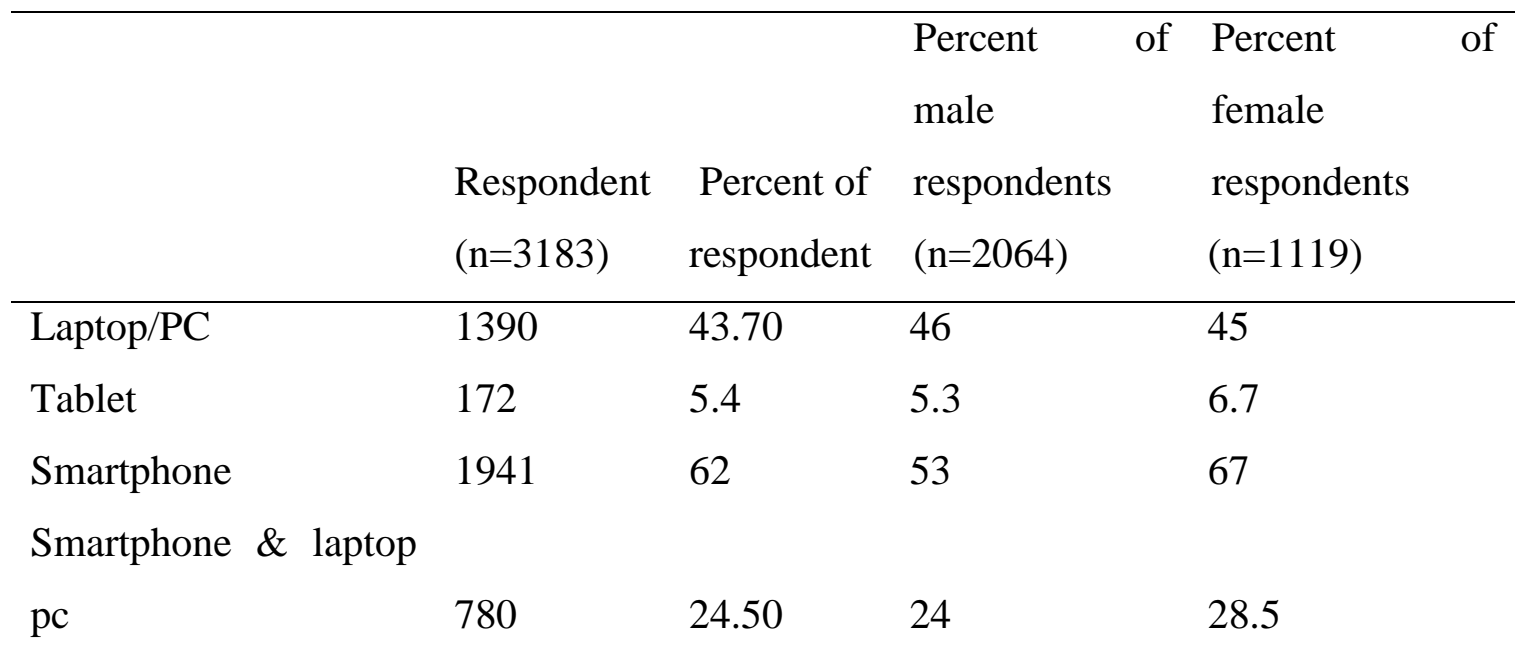

The table 4 presents the details of gadgets used by the respondents, 62 percent $(n=1941)$ were using smartphone, women were far ahead from men in the use of smartphone for the online news, 67 percent and 53 percent respectively. While 43.7 percent $(n=1390)$ respondents were using laptop and PC for the online news and 24.50 percent $(n=780)$ respondents were using smartphone, laptop and PC. Tablet was least utilize gadget by the respondents, as only 5.4 percent $(n=172)$ used tablet for online news reading.

Table 5: What is the credible source of information?

\begin{tabular}{lllll}
\hline & $\begin{array}{l}\text { Respondent } \\
(\mathrm{n}=3183)\end{array}$ & $\begin{array}{l}\text { Percent of male } \\
\text { respondent }\end{array}$ & $\begin{array}{l}\text { Percent of female } \\
\text { respondents } \\
(\mathrm{n}=2064)\end{array}$ & $\begin{array}{l}\text { respondents } \\
(\mathrm{n}=1119)\end{array}$ \\
\hline Companies website & 190 & 6 & 5.8 & 7.2 \\
Government Website & 996 & 31.20 & 26 & 29.2 \\
Social Media & 670 & 21.26 & 22.5 & 18.5 \\
Media/News & & & & \\
organizations & 1920 & 60.3 & 59.7 & 54.7 \\
Personal Blogs & 223 & 7 & 7 & 7.6
\end{tabular}

From the table 5, it is inferred that websites of news organizations is the most credible source of information for most respondents 60.3 percent $(n=1920)$, Information in the personal blogs and websites of companies were least credible source of information, 7 percent $(n=223)$ and 6 percent $(n=190)$ respectively. The second reliable source of inform on Internet is government 
websites, as research shows 31.2 percent $(n=996)$ respondents believes these websites are providing credible information. 21.26 percent $(n=670)$ of all respondents believes social media provide reliable information. Interestingly women readers have more faith on government websites, private companies and personal blogs as compare to men.

Table 6: Frequency of reading online news

\begin{tabular}{lllll}
\hline & & & $\begin{array}{l}\text { Percent } \\
\text { male }\end{array}$ & $\begin{array}{l}\text { of } \\
\text { Respondent } \\
\text { female }\end{array}$ \\
Frequency of reading online news & $\begin{array}{l}\text { Percent of } \\
(\mathrm{n}=3183)\end{array}$ & $\begin{array}{l}\text { respondent } \\
\text { responts } \\
(\mathrm{n}=2064)\end{array}$ & $\begin{array}{l}\text { respondents } \\
(\mathrm{n}=1119)\end{array}$ \\
\hline $\begin{array}{l}\text { Morning } \\
\text { Morning and Evening }\end{array}$ & 738 & 23.2 & 22.2 & 19.8 \\
$\begin{array}{l}\text { Morning, Afternoon and Evening } \\
\text { Morning, Afternoon, Evening and }\end{array}$ & 302 & 25.5 & 26 & 31.7 \\
$\begin{array}{l}\text { Night } \\
\text { Many time }\end{array}$ & 216 & 6.5 & 10.3 & 8.7 \\
& 1114 & 35 & 35.3 & 35
\end{tabular}

The table 6 indicates that a vast majority of the online news readers, 35 percent $(n=1114)$ were reading news many times in a day. Whereas 25.5 percent $(n=811)$ respondents says they are reading news on net only morning and evening, interestingly women were reading news in the morning and evening more than male readers 31.7 percent and 26 percent respectively. On the other hand only 23.2 percent $(n=738)$ readers says they read online news only in the morning. Whereas in print media most of the people read newspaper in the morning. Only 9.5 percent $(n=302)$ respondent were reading news in the morning, afternoon and evening, in which women read 10.3 percent and male 9.5 percent. Only 6.8 percent $(n=216)$ respondents read news in the morning, afternoon, evening and night, in which 6.2 percent men and 4.7 percent were women.

Table 7: How news consumer is getting news content ?

\begin{tabular}{llllll}
\hline & & & Percent & of & Percent of \\
News & Respondent & Percent of & male & female \\
content & $(n=3183)$ & respondent & respondents & respondents \\
\hline
\end{tabular}




\begin{tabular}{|c|c|c|c|c|}
\hline & & & $(n=2064)$ & $(n=1119)$ \\
\hline Photo Gallery & 1063 & 33.40 & 27.6 & 30.8 \\
\hline Video Gallery & 445 & 14 & 10.3 & 13.2 \\
\hline News in Text & 1909 & 60.30 & 57 & 45.6 \\
\hline Related News & Reference & & & \\
\hline links & 764 & 24.30 & 23.7 & 20.1 \\
\hline
\end{tabular}

As per the table 7, majority 60.3 percent $(n=1909)$ of the online news consumers likes to read the news. In which, 57 percent male and 45.5 percent women likes to read the news. On the other hand 33.4 percent $(n=1063)$ respondents like the photo gallery, 30.8 percent women likes to see news through the photos while only 27.6 percent male are getting news through the photo gallery. Whereas 24.3 percent $(n=764)$ like the related news reference links, 23.7 percent male and 20.1 percent women likes it. Rest of the people 14 percent $(n=445)$ like the video gallery in online newspapers. Women like video news 13.2 percent more than male 10.3 percent.

\section{Discussion}

This paper studied the habits of online news readers in India. The findings indicate that online newspapers is considered most credible information provider on the Internet, apart from other three traditional media- radio, television and print. In the age of information technology, the new emerged medium of information gathering is become a powerful tool. Men outnumber women in using Internet for news reading. As per the study, 64.8 percent respondents were men and only 35.2 percent respondents were women.

The information available online is easy to find through search engines, but which source is trustworthy is a big question. Now the entire private and public sector upload their news on their respective websites. Not only this even celebrities update their status on their website giving an easier route of access to their fans. Most of them have their public relations department and some of them hire PR specialist for this purpose. Majority of Indian readers 60.3 percent believe, media websites are providing credible information. Only few readers believe on personal blogs, social media and the government websites. Interestingly, women readers have more faith on government websites, private companies and personal blogs as compared to men. 
Most of the smartphone users in India are using Internet. There are many reasons for using Internet on mobile phones, most important factor is many service provider offering $3 \mathrm{G} / 4 \mathrm{G}$ speeds, makes opening of websites easy. Another reason is Internet on mobile has become affordable. The explosion of mobile Internet usage in India is one of the major reasons for the growth of online media. As per the survey, most of the online news readers 62 percent are using smartphone for reading news. All the big media houses have their news apps which is easy to use and provide latest news on one click.

As per the survey, majority (97 percent) online readers are also using traditional media for the news, they are regular consumers of traditional news media as well as online media.

The study shows 35 percent online news readers are reading online news many times in a day. It is because, all the traditional media have started their online papers and updating their website regularly with latest news.

People of all age group are using Internet for their daily need on various gadgets available in the market. India is considered a youth nation around the world, the present study shows the majority of online readers are youth below the age of 30, maximum 41.80 percent $(n=1329)$ news consumers are from 20-30 age group and 21.80 percent ( $n=694)$ from 15-20 age group.

\section{Conclusion}

In the Western world, newspaper circulation is drastically going down, many news orgnisations have stopped printing the newspapers, and they only provide the news on their websites. But in other parts of the world, print media has maintained its place particularly in India and China.

In India Internet user are growing rapidly and most of the newspapers have started their online newspapers, which are completely accessible through the Internet. The study reveals that news websites are the most credible source of information for the online users. Media industry should have maintain the trust of readers and provide trustworthy news items. They should strengthen their online edition team, as online media is the future of media industry. All the online newspapers should send the news alerts (headlines of main stories with links to 
entire story) on e-mails, WhatsApp, Twitter and Facebook, it is very important for online news users.

The study revealed that only 35 percent readers are going online many time for getting latest news. It is noticed that many newspapers website is not user friendly. Some sites are giving popup advertisements with all the news even on the clicks on the links. Online reader avoids those sites which are giving popup advertisements. To bring more readers to the websites, always publish all kind of news content, moreover their website should be open in all the browsers even during slow Internet speed. All the media houses should target the smartphone users, as per the recent study, India will be the second in the world for using Smartphone in 2016. Mobile apps should be very light preferably without the ads. Automatic refresh of apps option should be included; media organization should update their Facebook, Twitter and other social media with latest news headline and link. 


\section{References}

Althaus, S. L., \& Tewksbury, D. (2000). Patterns of Internet and traditional news media use in a networked community. Political Communication, 17, 21-45.

Andrews, D., Nonnecke, B., \& Preece, J. (2003). Electronic Survey Methodology: A Case Study in Reaching Hard-to-Involve Internet Users. International Journal of HumanComputer Interaction, 185-210.

Bachmann, D., \& Elfrink, J. (1996). Tracking the progress of e-mail versus snail-mail. Marketing Research, 8 (2), 31-35.

Barthelemy, S. (2011). The Future of Print Media. Retrieved Jan 4, 2015, from www.sipa.columbia.edu/academics/workshops/documents/WorldNewsmediaInnovati onsStudy-CapstoneWorkshopSpring2011-ABRIDGED.pdf

Burgess, S. R., \& Jones, K. K. (2010). Reading and media habits of college students varying by sex and remedial status. College Student Journal, 44(2) (Jun2010 Part B), 492-508. Retrieved January, 19, 2015, from http://www.ebscohost.com/academic/academicsearch-premier

Domingo, \& David, H. (2008). Weblogs and journalism: a typology to explore the blurring boundaries. Nordicom Review, 29 (1): 3-15.

Deuze, M. (1999). Journalism And The Web: An Analysis Of Skills And Standards In An Online Environment. International Communication Gazette, 61(5), 373-390.

Ferguson, D., \& Perse, E. (2000). The World Wide Web as a Functional Alternative to Television. Journal of Broadcasting \& Electronic Media, 155-174.

Fox, S., Rainie, L., Larsen, E., Horrigan, J., Lenhart, A., Spooner, T., \& Carter, C. (2001). Wired Seniors. The Pew Internet and American Life Project. Retrieved January 6, 2015, from http://www.pewinternet.org/2001/09/09/wired-seniors/

Flanagin, A., \& Metzger, M. (2000). Perceptions of Internet Information Credibility. Journalism \& Mass Communication Quarterly, 77(3), 515-540.

Flanagin, A., \& Metzger, M. (2001). Internet use in the contemporary media environment. Human Communication Research, (27), 153-181.

Garrison, B. (1996). Successful strategies for computer-assisted reporting. Mahwah, NJ: L. Erlbaum.

Garton, L., Haythornthwaite, C., \& Wellman, B. (1999). Studying on-line social networks. In S.Jones (Ed.), Doing Internet Research: Critical Issues and Methods for Examining the Net (pp. 75-105). Thousand Oaks, CA : Sage. 
India to overtake US in Smartphone by 2016. (2014, December 24). Retrieved April 7, 2015, from http://indiainbusiness.nic.in/newdesign/index.php?param=newsdetail/10367

Kaufman, D., Stasson, M., \& Hart, J. (1999). Are the tabloids always wrong or is that just what we think? Need for cognition of perceptions of articles in print media. Journal of Applied Social Psychology, 29: 1984-1997.

Keefe, D. (1990). Persuasion: Theory and research. Newbury Park, Calif.: Sage Publications.

Llieva, J., Baron, S., \& Healey, N. M. (2002). Online surveys in marketing research: Pros and cons. International Journal of Market Research, 44 (3), 361-367.

Mings, Susan M. (1997). Uses and Gratifications of online newspapers: A Preliminary Study. Electronic Journal of Communication, 7.

Nie, N. H., \& Erbring, L. (2000). Internet and Society: A Preliminary Report. Palo Alto, CA : Stanford Institute for the Quantitative Study of Society Press.

Nie, N., Hillygus, S. \& Erbring, L. (2002). Internet use, interpersonal relations and sociability: Findings from a detailed time diary study. In B.Wellman (Ed.), The Internet in Everyday Life (pp. 215-243). London : Blackwell Publishers.

Purcell, K., Rainie, L., Mitchell, A., Rosenstie, T., \& Olmstead, K. (2010, February 28). Understanding the Participatory News Consumer. Retrieved Jan 5, 2015, from http://www.pewinternet.org/2010/03/01/understanding-the-participatory-newsconsumer/

Stanton, J. M. (1998). An empirical assessment of data collection using the Internet. Personnel Psychology, 51 (3), 709-725.

Stempel, G., Hargrove, T., \& Bernt, J. (2000). Relation of Growth of Use of the Internet to Changes in Media Use from 1995 to 1999. Journalism \& Mass Communication Quarterly, 71-79.

Taylor, H. (2000). Does Internet research work? Comparing electronic survey results with telephone survey. International Journal of Market Research, 42 (1), 51-63.

The Internet News Audience Goes Ordinary. (1999, January 13). Retrieved November 24, 2014, from http://www.people-press.org/1999/01/14/the-internet-news-audience-goesordinary/

Wathen, C., \& Burkell, J. (2002). Believe it or not: Factors influencing credibility on the Web. Journal of the American Society for Information Science and Technology, 53(2), 134-144. 
Wellman, B. (1997). An electronic group is virtually a social network. In S.Kiesler (Ed.), Culture of the Internet (pp. 179-205). Mahwah, NJ : Lawrence Erlbaum.

Witmer, D. F., Colman, R. W., \& Katzman, S. L. (1999). From paper-and-pencil to screenand-keyboard: Toward a methodology for survey research on the Internet. In S.Jones (Ed.), Doing Internet Research: Critical Issues and Methods for Examining the Net (pp. 145-161). Thousand Oaks, CA : Sage.

Yun, G. W., \& Trumbo, C. W. (2000). Comparative response to a survey executed by post, email, and web form. Journal of Computer-Mediated Communication, 6 (1). 